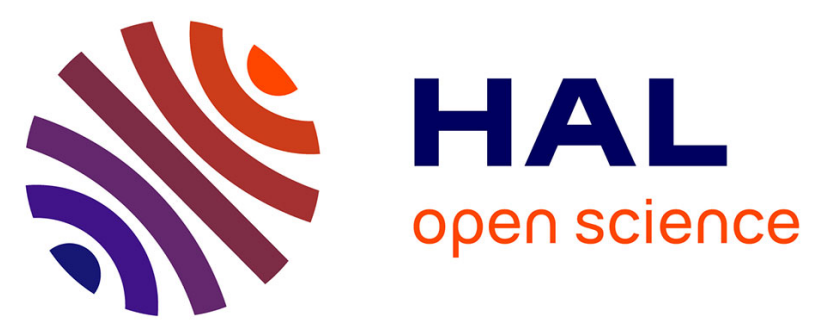

\title{
Desulfamplus magnetovallimortis gen. nov., sp nov., a magnetotactic bacterium from a brackish desert spring able to biomineralize greigite and magnetite, that represents a novel lineage in the Desulfobacteraceae
} Elodie C. T. Descamps, Caroline Monteil, Nicolas Menguy, Nicolas Ginet, David Pignol, Dennis A. Bazylinski, Christopher T. Lefèvre

\section{To cite this version:}

Elodie C. T. Descamps, Caroline Monteil, Nicolas Menguy, Nicolas Ginet, David Pignol, et al.. Desulfamplus magnetovallimortis gen. nov., sp nov., a magnetotactic bacterium from a brackish desert spring able to biomineralize greigite and magnetite, that represents a novel lineage in the Desulfobacteraceae. Systematic and Applied Microbiology, 2017, 40 (5), pp.280-289. 10.1016/j.syapm.2017.05.001 . hal-01640027

\section{HAL Id: hal-01640027 \\ https://hal.science/hal-01640027}

Submitted on 15 May 2018

HAL is a multi-disciplinary open access archive for the deposit and dissemination of scientific research documents, whether they are published or not. The documents may come from teaching and research institutions in France or abroad, or from public or private research centers.
L'archive ouverte pluridisciplinaire HAL, est destinée au dépôt et à la diffusion de documents scientifiques de niveau recherche, publiés ou non, émanant des établissements d'enseignement et de recherche français ou étrangers, des laboratoires publics ou privés. 
1 Desulfamplus magnetovallimortis gen. nov., sp. nov., a magnetotactic bacterium from

2 a brackish desert spring able to biomineralize greigite and magnetite, that 3 represents a novel lineage in the Desulfobacteraceae

5 Elodie C. T. Descamps ${ }^{\mathrm{a}}$, Caroline L. Monteil ${ }^{\mathrm{a}}$, Nicolas Menguy ${ }^{\mathrm{b}}$, Nicolas Ginet ${ }^{\mathrm{a}, \mathrm{c}}$, David 6 Pignol $^{\mathrm{a}}$, Dennis A. Bazylinski ${ }^{\mathrm{d}}$, Christopher T. Lefèvre ${ }^{\mathrm{a}, *}$

8 a CNRS/CEA/Aix-Marseille Université, UMR7265 Institut de biosciences et 9 biotechnologies, Laboratoire de Bioénergétique Cellulaire, 13108, Saint Paul lez 10 Durance, France

11 b Institut de Minéralogie, de Physique des Matériaux et de Cosmochimie, UMR 7590 12 CNRS - UPMC - MNHN - Sorbonne Université, 4 place Jussieu, 75252 Paris cedex 05, 13 France ${ }^{\mathrm{c}}$ CNRS/Aix-Marseille Université, UMR7283 Laboratoire de Chimie Bactérienne, 14 13009, Marseille, France

15 d School of Life Sciences, University of Nevada at Las Vegas, Las Vegas, NV, 8915416 4004, USA

19 Corresponding author at: CEA Cadarache, Biosciences and Biotechnolgies Institute, 2013108 Saint Paul lez Durance, France. Tel.: +33 442253293.

21 E-mail address: christopher.lefevre@cea.fr (C.T. Lefèvre) 


\section{ABSTRACT}

23 A magnetotactic bacterium, designated strain $\mathrm{BW}-1^{\mathrm{T}}$, was isolated from a brackish spring 24 in Death Valley National Park (California, USA) and cultivated in axenic culture. The 25 Gram-negative cells of strain $\mathrm{BW}-1^{\mathrm{T}}$ are relatively large and rod-shaped and possess a 26 single polar flagellum (monotrichous). This strain is the first magnetotactic bacterium 27 isolated in axenic culture capable of producing greigite and/or magnetite nanocrystals 28 aligned in one or more chains per cell. Strain BW-1 ${ }^{\mathrm{T}}$ is an obligate anaerobe that grows 29 chemoorganoheterotrophically while reducing sulfate as a terminal electron acceptor. 30 Optimal growth occurred at $\mathrm{pH} 7.0$ and $28^{\circ} \mathrm{C}$ with fumarate as electron donor and carbon 31 source. Based on its genome sequence, the $\mathrm{G}+\mathrm{C}$ content is $40.72 \mathrm{~mol} \%$. Phylogenomic

32 and phylogenetic analyses indicate that strain $\mathrm{BW}-1^{\mathrm{T}}$ belongs to the Desulfobacteraceae 33 family within the Deltaproteobacteria class. Based on average amino acid identity, strain

$34 \mathrm{BW}-1^{\mathrm{T}}$ can be considered as a novel species of a new genus, for which the name 35 Desulfamplus magnetovallimortis is proposed. The type strain of Desulfamplus 36 magnetovallimortis is $\mathrm{BW}-1^{\mathrm{T}}\left(\mathrm{JCM} 18010^{\mathrm{T}}-\mathrm{DSM} 103535^{\mathrm{T}}\right)$.

41 Key words: Desulfamplus magnetovallimortis, BW-1, magnetotactic bacteria, greigite, 42 magnetite, magnetotaxis, magnetosome, Deltaproteobacteria, sulfate-reducing bacteria. 
Introduction

Magnetotactic bacteria represent a phylogenetically, ecologically and metabolically diverse group of prokaryotes able to biomineralize single-magnetic-domain nanocrystals of magnetite (an iron oxide ( $\left.\mathrm{Fe}(\mathrm{II}) \mathrm{Fe}(\mathrm{III})_{2} \mathrm{O}_{4}\right)$ ) or greigite (an iron sulfide $\left.\left(\mathrm{Fe}(\mathrm{II}) \mathrm{Fe}(\mathrm{III})_{2} \mathrm{~S}_{4}\right)\right)$ in specific organelles [5]. These organelles, called magnetosomes, are aligned in one or more chains within the cytoplasm and cause cells to actively swim along the Earth's magnetic field lines [19]. This behavior, termed magnetotaxis, makes the search for optimal concentrations of certain nutrients and redox conditions within water columns and sediments more efficient by simplifying a three-dimensional search to

53 a linear search [19].

Although magnetotactic bacteria were discovered 40 years ago [11], relatively 55 few strains have been cultivated in pure culture. Officially described and cultured 56 magnetotactic species are all magnetite-producers and belong to the genera 57 Magnetospirillum [36,37,41], Desulfovibrio [40], Magnetovibrio [10], Magnetococcus 58 [9] and Magnetospira [55]. The candidate genus name of Magnetoglobus has also been 59 officially proposed for a magnetotactic multicellular prokaryote [2].

Greigite-producing magnetotactic bacteria were first described in 1983 [17] but the mineral composition of the crystals in the magnetosomes of these organisms was only identified in 1990 [16,35]. Until recently, they were thought to be confined to marine

63 habitats [45]. There are two known morphological types of greigite-producers: a group of 64 morphologically unique, multicellular magnetotactic prokaryotes (MMPs), and a group of 65 large rod-shaped bacteria [46]. While a good deal of information has been acquired 66 regarding the MMPs from culture-independent, environmental [4,8,44,53,57] and 67 genomics studies [1,3,24], their isolation in axenic culture has not yet been successful, 68 although Candidatus Magnetoglobus multicellularis was co-cultured in a medium where 69 cells reduced sulfate and used succinate as an electron donor [3]. The MMP group 70 represents an assemblage of obligately multicellular organisms that consist of about 107160 genetically identical cells and is phylogenetically affiliated with the 72 Desulfobacteraceae family within the Deltaproteobacteria class of the Proteobacteria 
73 phylum $[13,14,44,53,57,58]$. The large rod-shaped greigite and/or magnetite-producing

74 bacteria have been studied for several decades using culture-independent techniques from

75 environmental samples $[6,7,21,43,45]$ but have only been phylogenetically identified

76 [30,52] and cultured [30] recently. The greigite-producing, rod-shaped bacteria also

77 belong to the Desulfobacteraceae family [30].

The first isolation and cultivation of a large, rod-shaped greigite-producing magnetotactic bacterium, referred to as Candidatus Desulfamplus magnetomortis

80 (renamed here Desulfamplus magnetovallimortis) strain BW-1, was recently described

81 [30]. In silico analyses of this organism revealed the presence of two different 82 magnetosome gene clusters. Based on comparative genomics, one magnetosome gene 83 cluster was proposed to be responsible for greigite biomineralization and the other for 84 magnetite synthesis [30,32]. The presence of two similar clusters was also identified in 85 the MMP Ca. Magnetomorum strain HK-1 collected from samples from the North Sea, 86 Germany, supporting the ability of this bacterium to synthesize magnetite and greigite 87 magnetosomes. Magnetosome genes involved in greigite formation were first described 88 in $\mathrm{Ca}$. Magnetoglobus multicellularis [1]. Finally, greigite magnetosome genes were also 89 identified in a draft genome of an uncultivated bacterium belonging to the candidate 90 phylum Latescibacteria [34]. Although there is no evidence that this bacterium is able to 91 produce greigite, it is possible that greigite biomineralization extends to this phylum as 92 well as the Deltaproteobacteria.

Desulfamplus magnetovallimortis strain $\mathrm{BW}-1^{\mathrm{T}}$ (Bad Water-1) is the subject of 94 the current study. This magnetotactic bacterium was isolated from a brackish spring at 95 Badwater Basin, Death Valley National Park, California, USA [30]. Using cultivation 96 experiments and genomic approaches, here we fully characterize and name this strain that 97 represents the first greigite-producing magnetotactic bacterium isolated in axenic culture.

\section{Materials and methods}


Strain $\mathrm{BW}-1^{\mathrm{T}}$ was isolated from mud and water collected from the brackish spring 102 located at Badwater Basin in Death Valley, California, USA [30]. For isolation of strain

$103 \mathrm{BW}-1$, cells of magnetotactic bacteria were first magnetically concentrated from water 104 samples using the magnetic capillary racetrack technique [56] and then inoculated into a 105 modified semisolid, oxygen concentration gradient $\left(\left[\mathrm{O}_{2}\right]\right.$-gradient) medium based on a 106 growth medium originally designed for Desulfobacterium vacuolatum. The medium 107 consisted of an artificial seawater (ASW) base diluted to the approximate salinity of the 108 water sample, containing (per liter): $\mathrm{NaCl}, 20 \mathrm{~g} ; \mathrm{MgCl}_{2} \bullet 6 \mathrm{H}_{2} \mathrm{O}, 3 \mathrm{~g} ; \mathrm{Na}_{2} \mathrm{SO}_{4}, 3 \mathrm{~g} ; \mathrm{KCl}, 0.5$ $109 \mathrm{~g}$; and $\mathrm{CaCl}_{2} \cdot 2 \mathrm{H}_{2} \mathrm{O}, 0.2 \mathrm{~g}$. To this was added (per liter) the following, in order, prior to 110 autoclaving: $50 \mu \mathrm{L}$ of $0.2 \%(\mathrm{wt} / \mathrm{vol})$ aqueous resazurin, $5 \mathrm{~mL}$ of modified Wolfe's 111 mineral elixir [19], $0.3 \mathrm{~g}$ of $\mathrm{NH}_{4} \mathrm{Cl}, 2.4 \mathrm{~g}$ of HEPES, $2 \mathrm{~g}$ of Casamino acids and $2 \mathrm{~g}$ of 112 Agar Noble (both from Difco). The $\mathrm{pH}$ of the medium was then adjusted to 7.0 prior to 113 autoclaving. Once the medium cooled to about $45^{\circ} \mathrm{C}$, the following solutions were added 114 (per liter), in order, from stock solutions (except for the cysteine, which was made fresh 115 and filter sterilized directly into the medium): $0.5 \mathrm{~mL}$ of vitamin solution [19]; $1.8 \mathrm{~mL}$ of $1160.5 \mathrm{M} \mathrm{KHPO}_{4} / \mathrm{KH}_{2} \mathrm{PO}_{4}$ buffer, $\mathrm{pH} 7.0 ; 3 \mathrm{~mL}$ of $0.01 \mathrm{M} \mathrm{FeCl}_{2}$ dissolved in $0.02 \mathrm{~N} \mathrm{HCl}$; 117 and L-cysteine to give a final concentration of $0.4 \mathrm{~g} / \mathrm{L}$. The medium $(10 \mathrm{~mL})$ was 118 dispensed into sterile, $15 \times 125 \mathrm{~mm}$ screw-capped test tubes. All cultures were incubated 119 at $28^{\circ} \mathrm{C}$ and, after approximately one week, an aggregate of cells formed in the anaerobic 120 zone of the medium. The large rod-shaped cells were not magnetotactic in this medium 121 and it was only when they were transferred in a specific liquid medium that cells became 122 magnetotactic. An axenic culture of strain $\mathrm{BW}-\mathrm{1}^{\mathrm{T}}$ was obtained after three successive 123 rounds of dilution to extinction in this latter medium. Purity of the cultures was 124 determined using light microscopy and by amplification and sequencing of the 16S rRNA 125 gene.

Media and culture conditions

127 For magnetosome formation, cells of strain $\mathrm{BW}-\mathrm{1}^{\mathrm{T}}$ were grown in BWM medium 128 in $250 \mathrm{~mL}$ Schott bottles containing $100 \mathrm{~mL}$ of liquid anaerobic medium closed by a cap 129 and a rubber stopper. The formula of the medium was (per liter): $20 \mathrm{~g} \mathrm{NaCl}, 3 \mathrm{~g}$ $130 \mathrm{MgCl}_{2} \bullet 6 \mathrm{H}_{2} \mathrm{O}, 3 \mathrm{~g} \mathrm{Na}_{2} \mathrm{SO}_{4}, 0.2 \mathrm{~g} \mathrm{CaCl}_{2} \cdot 2 \mathrm{H}_{2} \mathrm{O}$ and $0.5 \mathrm{~g} \mathrm{KCl}$. To a liter of the basal 
131 medium, $5 \mathrm{ml}$ modified Wolfe's mineral elixir [19], $50 \mu \mathrm{L} \mathrm{1 \%}$ aqueous resazurin, $0.3 \mathrm{~g}$

$132 \mathrm{NH}_{4} \mathrm{Cl}, 2.4 \mathrm{~g}$ 4-(2-hydroxyethyl)-1-piperazineethanesulfonic acid (HEPES) and $1 \mathrm{~g}$

133 fumaric acid were added and the $\mathrm{pH}$ adjusted to 7.5 with $10 \mathrm{M} \mathrm{NaOH}$. The medium was

134 then autoclaved. After autoclaving, $0.5 \mathrm{~mL}$ of an anaerobic stock solution of vitamins

135 [19]; $1.8 \mathrm{~mL}$ of $0.5 \mathrm{M} \mathrm{KHPO}_{4}$ buffer (pH 7.0); $2 \mathrm{~mL}$ or $10 \mathrm{~mL}$ of $10 \mathrm{mM} \mathrm{FeCL}_{2} \bullet 4 \mathrm{H}_{2} \mathrm{O}$

136 (in $0.02 \mathrm{M} \mathrm{HCl}$ ) and $0.4 \mathrm{~g}$ of freshly made filtered sterilized cysteine were added to the

137 medium. The medium was then bubbled with $\mathrm{O}_{2}$-free $\mathrm{N}_{2}$ for $30 \mathrm{~min}$. The medium was

138 inoculated with $5 \mathrm{~mL}$ of a culture in exponential growth phase and incubated at $22^{\circ} \mathrm{C}$.

Electron donors and acceptors were tested in this growth medium. The following

140 compounds were tested as terminal electron acceptors (sodium salts, when appropriate):

141 nitrate $(2 \mathrm{mM})$, nitrite $(2 \mathrm{mM})$, fumarate $(20 \mathrm{mM})$, trimethylamine oxide (TMAO; 15

$142 \mathrm{mM}$ ), dimethylsulfoxide (DMSO; $15 \mathrm{mM})$, sulfur $(5 \mathrm{mM})$, sulfite $(5 \mathrm{mM})$, thiosulfate (5

$143 \mathrm{mM})$, tetrationate $(5 \mathrm{mM})$, dithionite $(5 \mathrm{mM})$ and $\mathrm{N}_{2} \mathrm{O}$ (1 atm in the headspace). Except

144 for the tubes containing nitrous oxide $\left(\mathrm{N}_{2} \mathrm{O}\right)$, all others were flushed with $\mathrm{O}_{2}$-free $\mathrm{N}_{2}$. To

145 test for heterotrophic growth, potential carbon sources were added to tubes to give a final

146 concentration of $0.1 \%(\mathrm{wt} / \mathrm{vol}$ or $\mathrm{vol} / \mathrm{vol}$ ) using the BWM liquid medium minus fumaric

147 acid. The following carbon sources were tested (sodium salts for acids, L-enantiomers

148 were used for amino acids, D-enantiomers for sugars): alanine, aspartic acid, glutamic

149 acid, glutamine, glycine, isoleucine, leucine, proline, serine, valine, butanol, glucose,

150 casamino acids, yeast extract, butyrate, malate, pyruvate, acetate, fumarate, gluconic acid,

151 lactic acid and succinate. To test for autotrophic growth, fumaric acid was omitted from

152 the medium, $2.8 \mathrm{~mL}$ of a solution of $0.8 \mathrm{M} \mathrm{NaHCO}_{3}$ (autoclaved dry; sterile water added

153 after autoclaving to make the fresh stock solution) was added to the medium which was

154 then bubbled with $\mathrm{H}_{2}$ for $30 \mathrm{~min}$. If growth was observed, the culture was transferred

155 twice further in the same medium in triplicate. Fumaric acid was used as the positive

156 control and sterile $\mathrm{H}_{2} \mathrm{O}$ was used as the negative control. Tubes were incubated for at 157 least 3 weeks at $28^{\circ} \mathrm{C}$. 
Whole genome sequencing of Desulfamplus magnetovallimortis strain BW-1 was

160 previously described [31]. The draft genome sequence partially annotated was submitted

161 to the European Nucleotide Archive and carries the accession number PRJEB14757. The

162 genome was assembled using the MicroScope platform resulting in 108 scaffolds and 346

163 contigs for a total length of 6,784,998 bases. Automatic and manual sequence annotations

164 were performed using the MicroScope platform from the Genoscope [51]. There are

$16511.28 \%$ of Nosferatu Repeated Regions (excluding undetermined bases). CDS length is 166 about $942.13 \mathrm{bp}$ with an intergenic length of $210 \mathrm{bp}$. A total of $6,137 \mathrm{CDS}$ are present in 167 the genome.

Phylogenetic analysis

Evolutionary relationships between Desulfamplus magnetovallimortis $\mathrm{BW}-1^{\mathrm{T}}$ and 170 its relatives were investigated at both $16 \mathrm{~S}$ rRNA sequence and whole genome resolutions. 171 First, genomes of several Deltaproteobacteria type strains were downloaded from the 172 public database NCBI (updated up to March 2016) and uploaded into the MicroScope 173 platform. These included at least one representative of each order (Desulfobacterales, 174 Desulfarculales, Syntrophobacterales, Myxococcales, Bdellovibrionales, 175 Desulfuromonadales, Desulfurellales and Desulfovibrionales) with the exception of the 176 Desulfobacterales and Desulfovibrionales, for which several genomes were included in 177 the dataset. A core genome (i.e., genes detected in all genomes compared, for which 178 protein sequences shared $>50 \%$ identity over $>80 \%$ of their length), was defined with 179 the Microscope comparative genomics tool and categorized into several MicroScope gene 180 families (MICFAM). Among the 131 MICFAM shared by the 24 genomes, 70 were 181 represented by a unique sequence per genome and 32 out of those coded for ribosomal 182 proteins. Core amino acids sequences were aligned independently using MAFFT 7 [23]. 183 Alignments were trimmed to remove positions composed of more than $95 \%$ gaps and 184 concatenated into a single alignment of 23,813 amino acids positions among which 185 18,161 were polymorphic. A maximum-likelihood (ML) tree was built with RAxML 186 8.2.6 [47] under the GAMMA model of rate heterogeneity using empirical AA 187 frequencies and the LG substitution model (selected with the Bayesian criterion). A total 188 of 200 bootstrap replicates automatically determined by the MRE-based bootstopping 
189 criterion were conducted under the rapid bootstrapping algorithm, among which 100 were 190 sampled to generate proportional support values.

191 Only few genomes of members of the Desulfobacteraceae family are currently 192 available. Thus, a phylogenetic tree based on the 16S rRNA gene sequences was built to 193 determine the relatedness of Desulfamplus magnetovallimortis $\mathrm{BW}-1^{\mathrm{T}}$ within the existing 194 diversity of Desulfobacteraceae species already described. For this purpose, 43 195 sequences of cultured type strains $>1,200$ bp available in the Ribosomal Database Project 196 (https://rdp.cme.msu.edu) were downloaded, aligned and trimmed as described above. A 197 ML tree was also built following the same procedure than described above but under a 198 GAMMA model of rate heterogeneity, estimating a Generalized Time Reversible (GTR) 199 model for nucleotide substitution and an estimate of the proportion of invariable sites.

200 Chemotaxonomic analyzes

201 For fatty acid and respiratory quinones analyses, sulfate-reducing cells of strain

202 BW-1 ${ }^{\mathrm{T}}$, grown in liquid medium with fumarate as electron donor were harvested during 203 late exponential phase. Fatty acid analysis and respiratory quinones was carried out by 204 the Identification Service of the Deutsche Sammlung von Mikroorganismen und 205 Zellkulturen GmbH (DSMZ), Braunschweig, Germany. Fatty acids were extracted, 206 purified, methylated and quantified by gas chromatography using the standard Microbial 207 Identification System [22,27,38]. Respiratory quinones were analyzed by thin layer 208 chromatography using the standard Microbial Identification System [49,50].

209 Electron microscopy

210 Transmission electron microscopy (TEM) of whole cells was done using a Tecnai (FEI 211 Company, Hillsboro OR) model G2 Biotwin electron microscope using an accelerated 212 voltage of $100 \mathrm{kV}$. High resolution transmission microscopy (HRTEM) was carried out 213 on a Jeol $2100 \mathrm{~F}$ microscope. This machine, operating at $200 \mathrm{kV}$, is equipped with a 214 Schottky emission gun, an ultra-high-resolution pole piece, and an ultrathin window 215 JEOL X-ray Energy Dispersive Spectrometer. HRTEM images were obtained with a 216 Gatan US 4000 CCD camera. 
217 A drop of culture containing cells of strain $\mathrm{BW}-1^{\mathrm{T}}$ was deposited onto TEM 218 copper grids coated with a carbon film, which were then washed and dried in air. The 219 grids were stained with $1 \%$ uranyl acetate in particular to observe flagella.

\section{Results and discussion}

\section{Cell morphology}

223 Light microscopy and TEM observations show that cells of strain $\mathrm{BW}-1^{\mathrm{T}}$ are 224 relatively large, rod-shaped and possess a single polar flagellum that measures 3-4 times 225 the cell's body length (Fig. 1A). Although the majority of the cells are not motile in the 226 lag phase, most of the cells in the exponential and stationary phases are motile. Cells 227 have a smooth motility in the presence or absence of a magnetic field with an 228 approximate speed of $30 \mu \mathrm{m} \cdot \mathrm{s}^{-1}$. Cultured cells synthesize a large electron-dense 229 inclusion of unknown composition approximately $500 \mathrm{~nm}$ in diameter (Fig. 1B) that were 230 not observed in cells collected from the environment. Specific chemical elements in this

231 inclusion were not detected using energy-dispersive X-ray spectroscopy (Fig. 1C). This 232 inclusion was more commonly observed in cells in stationary or early exponential growth 233 phases. 

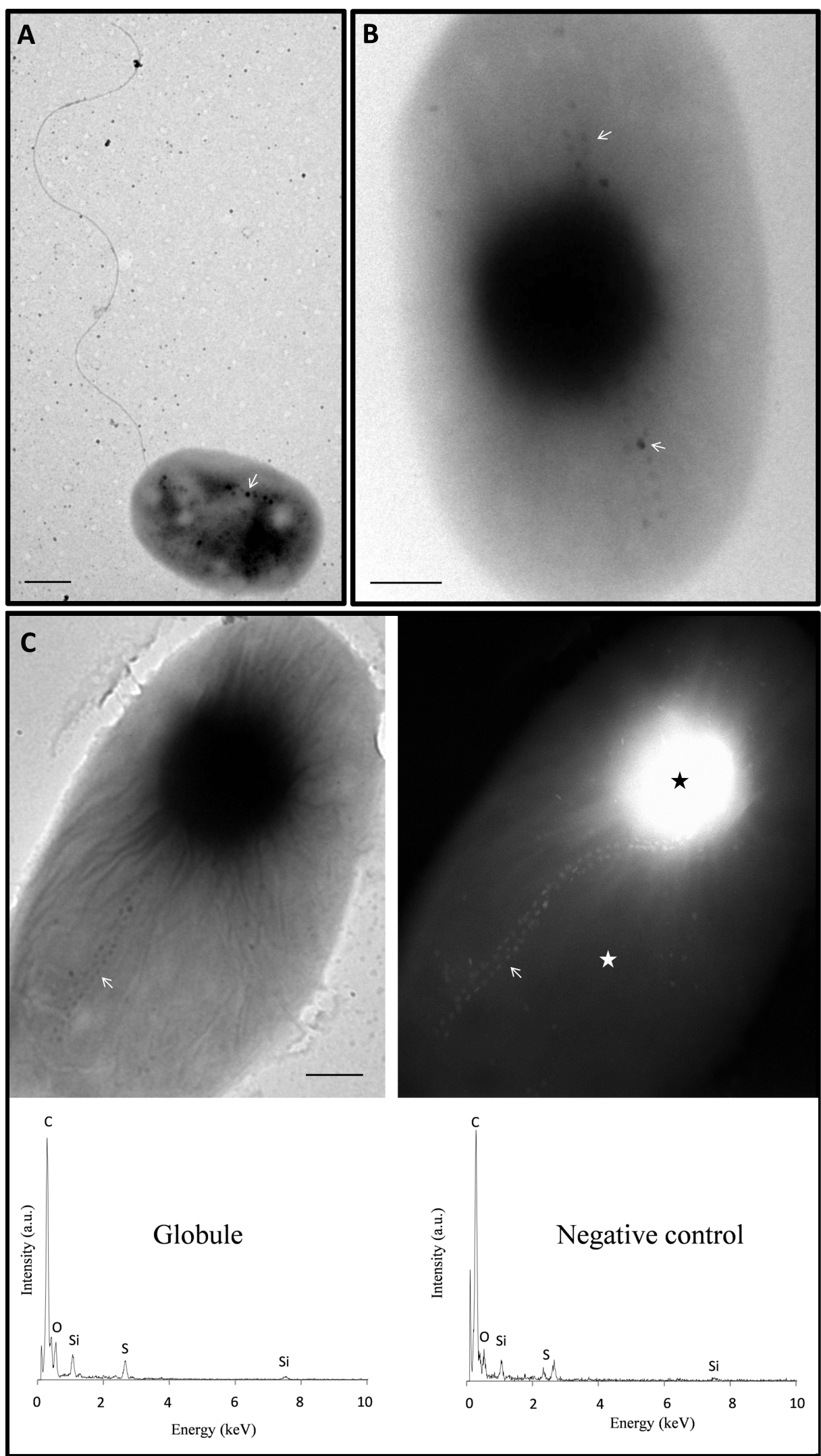
235 Fig. 1. Transmission electron microscope (TEM) images of whole cells of strain $B W-1^{\mathrm{T}}$ showing (A) the 236 single polar flagellum and (B) the large inclusion of unknown composition and function. (C) TEM and 237 scanning-transmission electron microscope (STEM) images showing a large inclusion analyzed with 238 energy-dispersive X-ray spectroscopy. Elemental spectrum of the inclusion (left; black star inside the 239 inclusion) compared to that of background (right; white star outside the inclusion) showing that the 240 inclusion is not composed by specific elements. White arrows indicate magnetosomes. Scale bars represent $241200 \mathrm{~nm}$.

243 Growth characteristics

244 Cells growing in BWM medium appeared to be more motile and contained more 245 magnetosomes than other growth media tested (see Magnetosomes section). To increase 246 the growth rate, yeast extract was added $(0.2 \mathrm{~g} / \mathrm{L})$ to BWM medium and the cultures 247 incubated at $28^{\circ} \mathrm{C}$. Under such conditions, cells were still motile but did not show any 248 magnetic response under the light microscope and only biomineralized weakly 249 crystallized particles as observed by TEM. The minimum doubling time during 250 exponential growth phase in modified BWM medium was about 6-8 hours. Physiological 251 as well as morphological properties of strain $\mathrm{BW}-1^{\mathrm{T}}$ are listed in Table 1 and compared to 252 closely related species.

254 Table 1. Selected characteristics that differentiate strain $\mathrm{BW}-1^{\mathrm{T}}$ from its closest relatives.

255 NR, Not reported; +, good growth; (+), poor growth; -, no growth. Reference strains: 1, Desulfobacterium 256 autotrophicum (data from [48] and [12]); 2, Desulfobacula toluolica (data from [26]); 3, Desulfotignum 257 balticum (data from [26]); 4, Desulfospira joergensenii (data from [18]); 5, Desulfoconvexum algidum 258 (data from [25]); Desulfobacter postgatei (data from [54]).

\begin{tabular}{|lccccccc|}
\hline Characteristic & BW-1 & 1 & 2 & 3 & 4 & 5 & 6 \\
\hline Cell morphology & $\begin{array}{c}\text { Rod to } \\
\text { oval }\end{array}$ & Oval & Oval & Rod & Vibrioid & Curved/vibrioid & $\begin{array}{c}\text { Rod to } \\
\text { ellipsiod }\end{array}$ \\
Magnetotactic & Yes & No & No & No & No & No & No \\
G-C content $(\operatorname{mol} \%)$ & 41 & 49 & 41 & 62 & 50 & 46 & 46
\end{tabular}




\begin{tabular}{|c|c|c|c|c|c|c|c|}
\hline $\begin{array}{l}\text { Optimum } \\
\left.\mathrm{NaCl} \mathrm{L}^{-1}\right)\end{array}$ & $15-25$ & & 20 & 20 & $12-20$ & $20-30$ & 5 \\
\hline $\begin{array}{l}\text { Optimum temperature } \\
\left({ }^{\circ} \mathrm{C}\right)\end{array}$ & 28 & $25-28$ & 28 & $28-32$ & $26-30$ & $14-16$ & 32 \\
\hline $\begin{array}{l}\text { Compounds used as } \\
\text { electron donor and } \\
\text { carbon source: }\end{array}$ & & & & & & & \\
\hline $\mathrm{H}_{2}+\mathrm{CO}_{2}$ & - & + & - & $(+)$ & + & + & - \\
\hline Formate & - & + & - & $(+)$ & + & + & - \\
\hline Acetate & - & + & - & $(+)$ & - & - & + \\
\hline Lactate & + & + & - & + & + & + & - \\
\hline Pyruvate & + & + & + & + & + & - & - \\
\hline Fumarate & + & + & + & + & + & + & - \\
\hline Succinate & + & + & + & $(+)$ & + & - & - \\
\hline Malate & + & + & + & + & - & + & - \\
\hline Fermentative growth & - & + & NR & + & - & + & - \\
\hline \multicolumn{8}{|l|}{ Electron acceptors: } \\
\hline Sulfite & - & - & NR & + & + & - & + \\
\hline Sulfur & - & - & NR & NR & + & + & - \\
\hline Thiosulfate & + & + & NR & + & + & + & + \\
\hline Nitrate & - & - & NR & - & - & - & - \\
\hline
\end{tabular}

260 Cells of strain BW-1 ${ }^{\mathrm{T}}$ grew anaerobically in the presence of sulfate and 261 thiosulfate, but not with nitrate, nitrite, fumarate, TMAO, DMSO, sulfite, sulfur, 262 tetrathionate, dithionite and $\mathrm{N}_{2} \mathrm{O}$ as terminal electron acceptors.

263 Because some magnetotactic strains of Desulfovibrio were recently shown to 264 respire with $\mathrm{O}_{2}$ [29], we tested $\mathrm{BW}-1^{\mathrm{T}}$ for this ability in an $\left[\mathrm{O}_{2}\right]$-gradient medium where 265 fumaric acid was added as the electron donor. In presence of sulfate, cells of strain BW$2661^{\mathrm{T}}$ only grew as aggregates below the oxic-anoxic interface. In absence of sulfate, no 267 growth was observed showing their inability to use $\mathrm{O}_{2}$ as electron acceptor. Strain BW-1 ${ }^{\mathrm{T}}$ 268 represents, to date, the only cultured magnetotactic bacterium unable to grow 269 microaerobically raising questions on the role(s) of magnetosomes in this bacterium. It is 270 possible that the conditions for aerobic growth of $\mathrm{BW}-1^{\mathrm{T}}$ remain to be elucidated or that 271 this ability was lost due to long term transfer of the culture under strictly anaerobic 272 conditions. Moreover, as it was reported for Desulfobacterium autotrophicum [48], strain $273 \mathrm{BW}-1^{\mathrm{T}}$ also has in its genome $c y d A B$ genes coding for a cytochrome d ubiquinol oxidase 
274 that could enable strain $\mathrm{BW}-1^{\mathrm{T}}$ to respire oxygen at low concentrations $[20,33]$. 275 Additionally, strain BW-1 ${ }^{\mathrm{T}}$ possesses a catalase-peroxidase (KatG), a selenocysteine276 containing peroxidase, rubrerythrin (Rbr) and a rubredoxin oxidoreductases (Rbo) for 277 oxygen detoxification.

278 Glutamate, glutamine, casamino acids, yeast extract, fumarate, lactate, malate, 279 pyruvate and succinate supported growth and are thus potential carbon sources for BW$280 \quad 1^{\mathrm{T}}$ (Table 1).

In BWM medium, cultures in exponential to late-exponential growth phase can be 282 stored for several weeks at $4^{\circ} \mathrm{C}$ before having to be transferred into fresh medium. For 283 long term storage, concentrated cells remained viable for several years in BWM medium 284 supplemented with $10 \%$ (final concentration) dimethylsulfoxide (DMSO) at $-80^{\circ} \mathrm{C}$.

Magnetosome biomineralization

Individual cells of strain $\mathrm{BW}-1^{\mathrm{T}}$ grown in $\mathrm{BWM}$ medium contained one or two magnetosome chains composed of magnetite and/or greigite (Fig. 2A and 2B). Magnetite crystals produced by $\mathrm{BW}-1^{\mathrm{T}}$ were consistently bullet-shaped, whereas greigite crystals were pleomorphic. When a cell biomineralizes magnetite and greigite magnetosomes,

290 both types of particles appear to be in the same chain likely sharing the same MamK 291 filament. We previously showed that the composition of magnetosome mineral crystals is 292 correlated with the concentration of hydrogen sulfide produced during growth (sulfate293 reduction) and affected by external environmental conditions, for example, redox 294 potential [6,30]. Indeed, when sulfide accumulates $(>0.3 \mathrm{mM})$ in the growth medium, 295 most magnetosomes contain greigite [30]. Since the initial description of strain BW-1 ${ }^{\mathrm{T}}$ 296 [26], we have improved in vitro magnetosome formation using BWM medium.

A relatively high concentration of iron in the medium $(>100 \mu \mathrm{M})$ appeared to be 298 favorable for magnetite rather than greigite formation. It seems that magnetite production 299 requires a high concentration of iron and a relatively high redox potential/low sulfide 300 concentration. Under such conditions, hydrogen sulfide, produced during growth and 301 sulfate reduction, is trapped as FeS by the relatively high concentration of iron in the 
302 growth medium. Conversely, greigite formation seems favored at lower iron 303 concentrations $(<20 \mu \mathrm{M})$ and low redox potential/high sulfide concentration. Under 304 these conditions, most of the hydrogen sulfide produced during cell growth is not trapped 305 and reduces the redox potential of the growth medium.


Fig. 2. Transmission electron microscope (TEM) images of cells of strain $B W-1^{T}$. (A) Cell grown in $B W M$ medium containing $100 \mu \mathrm{M}$ iron producing only magnetite magnetosomes, (B) high-resolution TEM (HRTEM) image of a magnetite crystal and corresponding selected area diffraction (SAED) of crystal viewed along the [110] zone axis (C). (D) Cell grown in BWM medium containing $20 \mu \mathrm{M}$ iron, cell produces only greigite magnetosomes, (E) HRTEM image of greigite crystal and corresponding SAED of crystal viewed along the [110] zone axis $(\mathrm{F})$.

Genes involved in magnetosome formation were previously described in detail 315 [32] and will not be further discussed here. We have grown strain BW-1 ${ }^{\mathrm{T}}$ consecutively 316 since 2010 under these anaerobic media and cells were always able to produce 317 magnetosomes. Non-magnetotactic mutant were never obtained in our growth conditions 318 as it was reported for other magnetotactic species. Indeed, the loss of magnetosome 319 formation and, thus, magnetotaxis by some cultivated MTB occurs relatively easily in 320 culture following the loss of magnetosome genes [15,42]. The absence of integrase and/or 321 transposase genes in close proximity of the magnetosome gene clusters [32] indicates that 322 this region is relatively stable in the genome of $\mathrm{BW}-1^{\mathrm{T}}$ and could explain why the 323 magnetotactic phenotype was never lost for this strain. 
Phylogeny of strain $B W-1^{T}$

325 Phylogenomics analyses confirmed the placement of strain $\mathrm{BW}-1^{\mathrm{T}}$ in the order 326 Desulfobacterales, more specifically in the family Desulfobacteraceae (Fig. 3A). The 327 three closest 16S rRNA gene sequences from type strains are those of Desulfobacterium 328 vacuolatum (93.3\%), Desulfobacterium autotrophicum (92.0\%) and Desulfobacula 329 toluolica (89.4). The closest genetically related species to $\mathrm{BW}-1^{\mathrm{T}}$, for which a whole 330 genome was sequenced and available, is Desulfobacterium autotrophicum HRM2 $331\left(=\mathrm{DSM} 3382^{\mathrm{T}}\right)$. Amino acid sequences from coding DNA sequences between the two 332 species are $58.15 \%$ identical based on the KostasLab two-way average amino acid 333 identity (AAI) calculator (http://enve-omics.ce.gatech.edu/aai/) (Fig. 4) [39]. Such a 334 genetic divergence between two genomes is generally found among bacterial strains 335 belonging to different genera [39]. A $16 \mathrm{~S}$ rRNA based tree containing $\mathrm{BW}-1^{\mathrm{T}}$ and 336 relatives confirmed that the most recent ancestor of $\mathrm{BW}-1^{\mathrm{T}}$ is shared with 337 Desulfobacterium species (Fig. 3B). Together with this phylogenetic evidence, ecological 338 and phenotypic features of $\mathrm{BW}-1^{\mathrm{T}}$ compared to those of its most closely related species 339 support our contention that $\mathrm{BW}-1^{\mathrm{T}}$ is the first representative of a new genus we name 340 here as Desulfamplus. In addition, among other compared characteristics, no

341 Desulfobacterium spp. were shown to be magnetotactic and magnetosome genes are not 342 present in the genome of Desulfobacterium autotrophicum HRM2, the only genome 343 sequenced and available from members of this genus [48]. Moreover, only 26-31\% of 344 their genome sequences are shared (Fig. 4).

345 The genus Desulfamplus likely contains several species since other magnetotactic 346 bacteria closely related to $\mathrm{BW}-1^{\mathrm{T}}$ have been described from natural environments $347[30,45,52]$. This clade appears to consist of at least two groups that could potentially be 348 divided into two separate genera based on 16S rRNA gene sequence divergence [28,30]. 349 New cultures and new genomes sequenced from those magnetotactic relatives to $\mathrm{BW}-1^{\mathrm{T}}$ 350 are clearly necessary to determine the number of different genera these groups represent 351 and how widespread this group of sulfate-reducing bacteria is. 


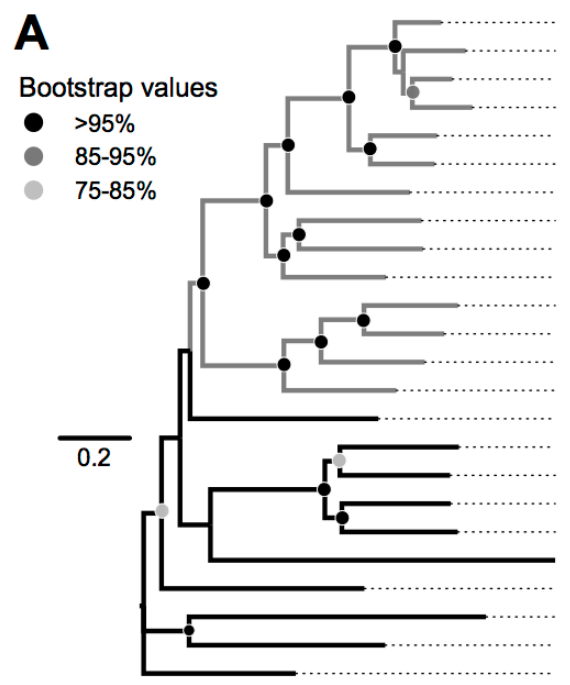

Desulfobacula toluolica Tol2

Desulfobacter postgatei 2ac9

Desulfospira joergensenii DSM10085

Desulfotignum balticum DSM7044

Desulfobacterium autotrophicum HRM2

Desulfamplus magnetovallimortis BW-1

Desulforegula conservatrix $\mathrm{Mb} 1 \mathrm{~Pa}$

Desulfococcus oleovorans $\mathrm{Hxd} 3$

Desulfatibacillum alkenivorans AK-01

Desulfatitalea tepidiphila S28bF

Desulfotalea psychrophila LSv54

Desulfocapsa sulfexigens DSM10523

Desulfobulbus propionicus DSM2032

Desulfurivibrio alkaliphilus AHT2

Desulfarculus baarsii DSM2075

Desulfomicrobium baculatum DSM4028

Desulfohalobium retbaense DSM5692

Desulfovibrio magneticus RS-1

Desulfonatronum thiodismutans MLF-1

Desulfurella acetivorans A63

Desulfomonile tiedjei DSM6799

Bdellovibrio bacteriovorus HD100

Myxococcus fulvus HW-1

Pelobacter carbinolicus DSM2380

B

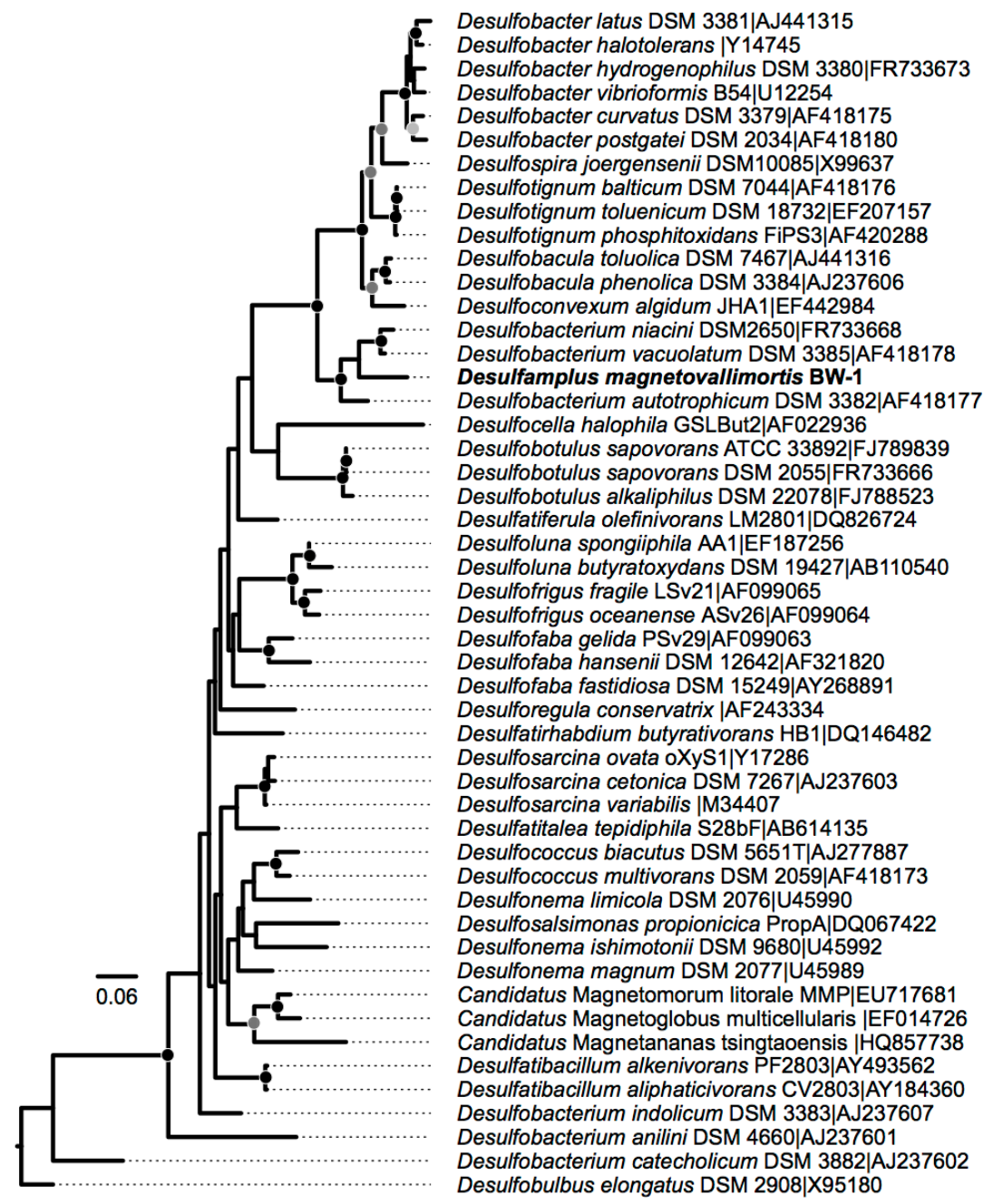

Desulfobulbus elongatus DSM 2908|X95180

354 Fig. 3. Phylogenetic position of Desulfamplus magnetovallimortis strain $\mathrm{BW}-1^{\mathrm{T}}$ within the

355 Deltaproteobacteria class. (A) Unrooted ML phylogeny showing the evolutionary relationships between

356 Desulfamplus magneotovallimortis strain BW-1 ${ }^{\mathrm{T}}$ with 23 sequenced genomes of Deltaproteobacteria type 
strains. The tree was built from the concatenated sequences of 70 aligned core proteins representing a total of 26,802 amino acids positions. The tree was inferred with the GAMMA model of rate heterogeneity and the LG matrix for describing protein evolution. Grey branches points out specifically the Desulfobacterales order. (B) ML phylogeny rooted with Desulfobulbus elongatus DSM2908 showing the evolutionary relationships of Desulfamplus magnetovallimortis strain $\mathrm{BW}-1^{\mathrm{T}}$ with 44 Desulfobacteraceae type strains specifically, based on 1470 aligned bp of 16S rRNA gene sequences. The tree was inferred estimating a GTRGAMMA model to describe nucleotide evolution. Trees were drawn to scale and branches length represents the number of base substitutions per site. A total of 200 and 500 bootstrap replicates automatically determined by the MRE-based bootstopping criterion were conducted for both trees respectively under the rapid bootstrapping algorithm to test robustness of the nodes, among which 100 were sampled to generate proportional support values.

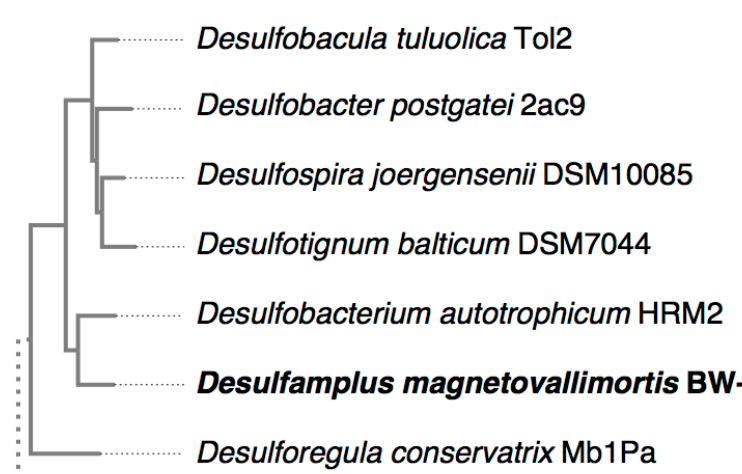

\section{Some additional metabolic features and details}

Fig. 4. Core genome sizes and percentages average amino acid identity (AAI) between Desulfamplus magnetovallimortis $\mathrm{BW}-1^{\mathrm{T}}$ and its closest relatives. Core genes are defined by MaGe as genes detected in both genomes, for which coding protein sequences shared a minimum of $50 \%$ identity over a minimum of $80 \%$ of their length. The radius of each dark grey circle is proportional to the number of detected genes. AAI values were estimated with the web-based KostasLab AAI calculator using reciprocal best hits (http://enve-omics.ce.gatech.edu/aai/) for each pair of genomes. The radius of each light grey circle is proportional to the AAI value. All data were organized according to the phylogeny given in Figure 3A. 
We previously showed evidence that strain $\mathrm{BW}-1^{\mathrm{T}}$ relies on sulfate-reduction for growth [30]. The genome of strain $\mathrm{BW}-1^{\mathrm{T}}$ contains several sets of genes that encode the major metabolic components for respiration and reduction of sulfate. We identified a number of these genes that encode key enzymes of this pathway including two sulfate 383 adenylyltransferases (MTBBW1_1630032 and MTBBW1_1740012), a set of 384 adenylylsulfate reductases (aprAB) (MTBBW1_350011 and MTBBW1_350012), a set of 385 sulfite reductases $(d s v A B D) \quad($ MTBBW1_1940076, MTBBW1_1940077, 386 MTBBW1_1940078 and MTBBW1_2280030), adenosyl phosphosulfate and quinone387 interacting membrane-bound oxidoreductase (qmoABC) (MTBBW1_350014, 388 MTBBW1_350015 and MTBBW1_350016).

Almost all cultured magnetotactic bacteria tested possess the capability of $\mathrm{N}_{2}$ 390 fixation [8] and strain $\mathrm{BW}-1^{\mathrm{T}}$ appears to be no exception as its genome contains a cluster 391 of nif genes (nifHEKBDJ) demonstrating it clearly has the potential to perform this 392 environmentally important process.

\section{Chemotaxonomy}

The cellular fatty acids of strain $\mathrm{BW}-1^{\mathrm{T}}$ were $\mathrm{C}_{16: 1} \omega 7 \mathrm{c}(25.2 \%$ of the total fatty 395 acids), $\mathrm{C}_{16: 0}(23.3 \%), \mathrm{C}_{17: 1} \omega 6 \mathrm{c}(13.1 \%), \mathrm{C}_{15: 0}(9.7 \%), \mathrm{C} 17: 0$ (4.9\%), $\mathrm{C}_{15: 1} \omega 6 \mathrm{c}(4.6 \%)$, $396 \mathrm{C}_{18: 1} \omega 7 \mathrm{c}(4.4 \%), \mathrm{C}_{17: 1} \omega 8 \mathrm{c}(3.5 \%), \mathrm{C}_{14: 0}(3.2 \%), \mathrm{C}_{18: 1} \omega 9 \mathrm{c}(1.2 \%)$. Strain $\mathrm{BW}-1^{\mathrm{T}}$ has a 397 fatty acid profile typical of members of the Desulfobacteraceae, where $\mathrm{C}_{16: 0}$ and $\mathrm{C}_{16: 1}$ 398 are generally the major fatty acids (Table 2).

400 Table 2. Major cellular fatty acids of Desulfamplus magnetovallimortis strain BW-1 ${ }^{\mathrm{T}}$ and 401 some phylogenetically related species.

402 Strains: Desulfamplus magnetovallimortis gen. nov., sp. nov. BW-1 ${ }^{\mathrm{T}}$; Desulfobacterium autotrophicum 403 strain HRM2 (data from [26]); Desulfotignum balticum strain $\operatorname{Sax}^{\mathrm{T}}$ [26]; Desulfospira joergensenii strain 404 B $331^{\mathrm{T}}[18]$; Desulfobacter postgatei strain DSM 2034 ${ }^{\mathrm{T}}$ [26]; Desulfobacula toluolica strain DSM $7467^{\mathrm{T}}$ $405[26]$. 


\begin{tabular}{|c|c|c|c|c|c|c|}
\hline Fatty acid & BW-1 ${ }^{\mathrm{T}}$ & $\begin{array}{c}\text { Desulfobacterium } \\
\text { autotrophicum }\end{array}$ & $\begin{array}{c}\text { Desulfotignum } \\
\text { balticum }\end{array}$ & $\begin{array}{l}\text { Desulfospira } \\
\text { joergensenii }\end{array}$ & $\begin{array}{c}\text { Desulfobacter } \\
\text { postgatei }\end{array}$ & $\begin{array}{c}\text { Desulfobacula } \\
\text { toluolica }\end{array}$ \\
\hline $\mathrm{C}_{14: 0}$ & 3.2 & 2.8 & 3.7 & 13.9 & 15.4 & 8.3 \\
\hline iso- $\mathrm{C}_{15: 0}$ & - & - & - & 1.8 & 0.7 & - \\
\hline $\mathrm{C}_{15: 1} \omega 9 \mathrm{c}$ & - & 6.5 & 0.8 & - & - & - \\
\hline $\mathrm{C}_{15: 0}$ & 9.7 & 5.1 & 0.2 & 1.3 & 3.1 & 1.6 \\
\hline $3-\mathrm{OH} \mathrm{C} \mathrm{C}_{14: 0}$ & 2.2 & - & - & 1.6 & - & - \\
\hline $\mathrm{C}_{16: 1} \omega 7 \mathrm{c}$ & 25.2 & - & - & - & - & - \\
\hline $\mathrm{C}_{16: 1} \omega 9 \mathrm{c}$ & - & 30.7 & 8.5 & 38.9 & 10.0 & 19.7 \\
\hline $\mathrm{C}_{16: 0}$ & 23.3 & 13.2 & 24.3 & 28.4 & 20.9 & 31.2 \\
\hline $\begin{array}{l}\mathrm{C}_{16: 0} 10- \\
\text { methyl }\end{array}$ & - & 7.4 & 14.0 & - & 11.2 & 17.6 \\
\hline $\mathrm{C}_{17: 1} \omega 11 \mathrm{c}$ & - & 10.5 & - & - & - & - \\
\hline $\mathrm{C}_{17: 1} \omega 8 \mathrm{c}$ & 3.5 & - & - & - & - & - \\
\hline $\mathrm{C}_{17: 1} \omega 6 \mathrm{c}$ & 13.1 & - & - & - & - & - \\
\hline $\mathrm{C}_{17: 0}$ cyclo & - & - & 19.5 & 2.4 & 31.5 & 2.6 \\
\hline $\mathrm{C}_{17: 0}$ & 4.9 & 2.9 & 0.4 & 0.6 & 2.3 & 0.7 \\
\hline $\mathrm{C}_{16: 0} 3-\mathrm{OH}$ & - & 0.5 & - & 2.3 & - & - \\
\hline $\mathrm{C}_{18: 1} \omega 13 \mathrm{c}$ & - & - & - & - & - & - \\
\hline $\mathrm{C}_{18: 1} \omega 11 \mathrm{c}$ & - & 2.7 & 7.4 & 5.3 & 1.2 & 6.0 \\
\hline $\mathrm{C}_{18: 1} \omega 9 \mathrm{c}$ & 1.2 & - & 3.7 & - & - & - \\
\hline $\mathrm{C}_{18: 1} \omega 7 \mathrm{c}$ & 4.4 & - & - & - & - & - \\
\hline $\mathrm{C}_{18: 0}$ & 0.4 & 1.1 & 9.8 & 0.7 & 0.5 & 3.1 \\
\hline iso- $\mathrm{C}_{19: 0}$ & - & - & 1.7 & - & - & 2.5 \\
\hline $\mathrm{C}_{19: 0}$ cyclo & - & - & 1.1 & - & - & - \\
\hline
\end{tabular}

407

408 Respiratory quinones analysis of strain BW-1 $1^{\mathrm{T}}$ shows the presence of MK-6 (5\%)

409 and MK-7 (95\%). This result is consistent with the respiratory quinones usually observed

410 in species of the Desulfocateraceae family, where the menaquinone MK-7 is generally

411 found as a major respiratory quinone.

412

413 Based on the data presented here, strain $\mathrm{BW}-1^{\mathrm{T}}$ is considered to represent a novel

414 species of a new genus, for which the name Desulfamplus magnetovallimortis gen. nov.,

415 sp. nov. is proposed.

416

417 Description of Desulfamplus gen. nov. 
419 N.L. sulfuratis sulfate; L.adj. amplus, -a, -um, large; N.L.n. masc. a large sulfate420 reducer).

421 Cells are Gram-negative, relatively large rods and motile by mean of a single 422 polar flagellum. They are strict anaerobes, using sulfate as terminal electron acceptor that 423 is reduced to sulfide. The two main cellular fatty acids are $C_{16: 1} \omega 7 \mathrm{c}$ and $\mathrm{C}_{16: 0}$ while the 424 major respiratory quinone is the menaquinone MK-7. The genus Desulfamplus belongs to 425 the Deltaproteobacteria class in the Proteobacteria phylum with its closest relative 426 species belonging to genus Desulfobacterium. The type species is Desulfamplus 427 magnetovallimortis $\mathrm{BW}-1^{\mathrm{T}}$. The Taxonumber is GA00026.

\section{Description of Desulfamplus magnetovallimortis sp. nov.}

Desulfamplus magnetovallimortis (ma.gne.to.val.li.mor'tis; ; L.adj.of greek origin 431 magnes magnetic; L.n.fem. valles, -is valley; L.n.fem. mors, mortis death; 432 magnetovallimortis referring to a magnetic bacterium isolated from the Death Valley in 433 California, USA, where the type strain was isolated from).

434 Species description is as for genus, with the following additional characteristics. 435 Cells are, on average, $2 \mu \mathrm{m}$ long and $1 \mu \mathrm{m}$ wide. Capable of chemoorganoheterotrophic 436 growth, using fumarate, lactate, pyruvate, malate and succinate as electron donors and 437 carbon sources. Sulfate and thiosulfate are used as terminal electron acceptors. Addition 438 of at least $10 \mathrm{~g} \mathrm{NaCl} \mathrm{L}^{-1}$ is necessary for growth; optimum $\mathrm{NaCl}$ concentration for growth 439 is $15-25 \mathrm{~g} \mathrm{~L}^{-1}$. Temperature requirements: $\mathrm{T}_{\min }, 10^{\circ} \mathrm{C} ; \mathrm{T}_{\mathrm{opt}}, 28^{\circ} \mathrm{C} ; \mathrm{T}_{\max }, 35^{\circ} \mathrm{C}$. The $\mathrm{pH}$ 440 range for growth is $6.5-7.5$; optimum 7. The G-C content of the genome is $41 \mathrm{~mol} \%$. The 441 major cellular fatty acids are $\mathrm{C}_{16: 1} \omega 7 \mathrm{c}, \mathrm{C}_{16: 0}, \mathrm{C}_{17: 1} \omega 6 \mathrm{c}, \mathrm{C}_{15: 0}, \mathrm{C} 17: 0, \mathrm{C}_{15: 1} \omega 6 \mathrm{c}, \mathrm{C}_{18: 1} \omega 7 \mathrm{c}$, $442 \mathrm{C}_{17: 1} \omega 8 \mathrm{c}$ and $\mathrm{C}_{14: 0}$. The type strain, $\mathrm{BW}-1^{\mathrm{T}}\left(=\mathrm{JCM} 18010^{\mathrm{T}}=\mathrm{DSM} 103535^{\mathrm{T}}\right)$ was isolated 443 from a brackish spring in Death Valley National Park (California, USA). The 444 Taxonumber is TA00086. 


\section{Acknowledgements}

447

448

449

450

451

452

453

454

455

456

457

458

459

460

461

462

463

464

465

466

467

468

469

470

471

472

473

474

475

476

477

478

479

480

481

This work was supported by a project from the Deutsche Forschungsgemeinschaft and the French National Research Agency (DFG-ARN: GROMA) and the ANR MEFISTO. D.A.B. is supported by U.S. National Science Foundation grant EAR1423939.

\section{References}

[1] Abreu, F., Cantão, M.E., Nicolás, M.F., Barcellos, F.G., Morillo, V., Almeida, L.G., do Nascimento, F.F., Lefèvre, C.T., Bazylinski, D.A., R de Vasconcelos, A.T., Lins, U. (2011) Common ancestry of iron oxide- and iron-sulfide-based biomineralization in magnetotactic bacteria. ISME J. 5(10), 1634-40, Doi: 10.1038/ismej.2011.35.

[2] Abreu, F., Martins, J.L., Silveira, T.S., Keim, C.N., de Barros, H.G.P.L., Filho, F.J.G., Lins, U. (2007) "Candidatus Magnetoglobus multicellularis", a multicellular, magnetotactic prokaryote from a hypersaline environment. Int. J. Syst. Evol. Microbiol. 57(Pt 6), 1318-22, Doi: 10.1099/ijs.0.64857-0.

[3] Abreu, F., Morillo, V., Nascimento, F.F., Werneck, C., Cantão, M.E., Ciapina, L.P., de Almeida, L.G.P., Lefèvre, C.T., Bazylinski, D.A., de Vasconcelos, A.T.R., Lins, U. (2014) Deciphering unusual uncultured magnetotactic multicellular prokaryotes through genomics. ISME J. 8(5), 1055-68, Doi: 10.1038/ismej.2013.203.

[4] Abreu, F.P., Silva, K.T., Farina, M., Keim, C.N., Lins, U. (2008) Greigite magnetosome membrane ultrastructure in "Candidatus Magnetoglobus multicellularis.” Int. Microbiol. Off. J. Span. Soc. Microbiol. 11(2), 75-80.

[5] Bazylinski, D.A., Frankel, R.B. (2004) Magnetosome formation in prokaryotes. Nat. Rev. Microbiol. 2(3), 217-30, Doi: 10.1038/nrmicro842.

[6] Bazylinski, D.A., Frankel, R.B., Heywood, B.R., Ahmadi, S., King, J.W., Donaghay, P.L., Hanson, A.K. (1995) Controlled biomineralization of magnetite (Fe3O4) and greigite (Fe3S4). Appl. Environ. Microbiol. 61(9), 3232-9.

[7] Bazylinski, D.A., Heywood, B.R., Mann, S., Frankel, R.B. (1993) Fe3O4 and Fe3S4 in a bacterium. Nature 366(6452), 218-218, Doi: 10.1038/366218a0.

[8] Bazylinski, D.A., Lefèvre, C.T., Schüler, D. (2013) Magnetotactic Bacteria. In: Rosenberg, E., DeLong, E.F., Lory, S., Stackebrandt, E., Thompson, F., (Eds.), The Prokaryotes, Springer Berlin Heidelberg, pp. 453-94.

[9] Bazylinski, D.A., Williams, T.J., Lefèvre, C.T., Berg, R.J., Zhang, C.L., Bowser, S.S., Dean, A.J., Beveridge, T.J. (2013) Magnetococcus marinus gen. nov., sp. nov., a marine, magnetotactic bacterium that represents a novel lineage (Magnetococcaceae fam. nov.; Magnetococcales ord. nov.) at the base of the 
Alphaproteobacteria. Int J Syst Evol Microbiol 63, 801-808., Doi:

10.1099/ijs.0.038927-0.

[10] Bazylinski, D.A., Williams, T.J., Lefèvre, C.T., Trubitsyn, D., Fang, J., Beveridge, T.J., Moskowitz, B.M., Ward, B., Schübbe, S., Dubbels, B.L., Simpson, B. (2013) Magnetovibrio blakemorei, gen. nov. sp. nov., a new magnetotactic bacterium (Alphaproteobacteria: Rhodospirillaceae) isolated from a salt marsh. Int. J. Syst. Evol. Microbiol. 65, 1824-33, Doi: 10.1099/ijs.0.044453-0.

[11] Blakemore, R. (1975) Magnetotactic Bacteria. Science 190(4212), 377-9, Doi: 10.1126/science. 170679.

[12] Brysch, K., Schneider, C., Fuchs, G., Widdel, F. (1987) Lithoautotrophic growth of sulfate-reducing bacteria, and description of Desulfobacterium autotrophicum gen. nov., sp. nov. Arch. Microbiol. 148(4), 264-74, Doi: 10.1007/BF00456703.

[13] Chen, Y.-R., Zhang, W.-Y., Zhou, K., Pan, H.-M., Du, H.-J., Xu, C., Xu, J.-H., Pradel, N., Santini, C.-L., Li, J.-H., Huang, H., Pan, Y.-X., Xiao, T., Wu, L.-F. (2016) Novel species and expanded distribution of ellipsoidal multicellular magnetotactic prokaryotes. Environ. Microbiol. Rep. 8(2), 218-26, Doi: 10.1111/1758-2229.12371.

[14] DeLong, E.F., Frankel, R.B., Bazylinski, D.A. (1993) Multiple evolutionary origins of magnetotaxis in bacteria. Science 259(5096), 803-6, Doi: 10.1126/science.259.5096.803.

[15] Dubbels, B.L., DiSpirito, A.A., Morton, J.D., Semrau, J.D., Neto, J.N.E., Bazylinski, D.A. (2004) Evidence for a copper-dependent iron transport system in the marine, magnetotactic bacterium strain MV-1. Microbiol. Read. Engl. 150(Pt 9), 2931-45, Doi: 10.1099/mic.0.27233-0.

[16] Farina, M., Esquivel, D., Debarros, H.G.P. (1990) Magnetic iron-sulfur crystals from a magnetotactic microorganism. Nature 343(6255), 256-8, Doi: $10.1038 / 343256 \mathrm{a} 0$.

[17] Farina, M., Lins de Barros, H., Esquivel, M.S., Danon, J. (1983) Ultrastructure of a magnetotactic bacterium. Biol Cell 48, 85-8.

[18] Finster, K., Liesack, W., Tindall, B.J. (1997) Desulfospira joergensenii, gen. nov., sp. nov., a new Sulfate-reducing Bacterium Isolated from Marine Surface Sediment. Syst. Appl. Microbiol. 20(2), 201-8, Doi: 10.1016/S0723-2020(97)80066-5.

[19] Frankel, R.B., Bazylinski, D.A., Johnson, M.S., Taylor, B.L. (1997) Magnetoaerotaxis in marine coccoid bacteria. Biophys. J. 73(2), 994-1000, Doi: 10.1016/S0006-3495(97)78132-3.

[20] Green, G.N., Fang, H., Lin, R.J., Newton, G., Mather, M., Georgiou, C.D., Gennis, R.B. (1988) The nucleotide sequence of the cyd locus encoding the two subunits of the cytochrome d terminal oxidase complex of Escherichia coli. J. Biol. Chem. 263(26), 13138-43.

[21] Heywood, B.R., Mann, S., Frankel, R.B. (1991) Structure, morphology and growth of biogenic greigite. In: Alpert, M., Calvert, P., Frankel, R.B., Rieke, P., Tirrell, D., (Eds.), Materials synthesis based on biological processes, vol. 218,, Materials Research Society, Pittsburgh, pp. 93-108.

[22] Kämpfer, P., Kroppenstedt, R.M. (1996) Numerical analysis of fatty acid patterns of coryneform bacteria and related taxa. Can. J. Microbiol. 42(10), 989-1005, Doi: $10.1139 / \mathrm{m} 96-128$. 
[23] Katoh, K., Standley, D.M. (2013) MAFFT multiple sequence alignment software version 7: improvements in performance and usability. Mol. Biol. Evol. 30(4), 77280, Doi: $10.1093 / \mathrm{molbev} / \mathrm{mst} 010$.

[24] Kolinko, S., Richter, M., Glöckner, F.-O., Brachmann, A., Schüler, D. (2014) Single-cell genomics reveals potential for magnetite and greigite biomineralization in an uncultivated multicellular magnetotactic prokaryote. Environ. Microbiol. Rep. 6(5), 524-31, Doi: 10.1111/1758-2229.12198.

[25] Könneke, M., Kuever, J., Galushko, A., Jørgensen, B.B. (2013) Desulfoconvexum algidum gen. nov., sp. nov., a psychrophilic sulfate-reducing bacterium isolated from a permanently cold marine sediment. Int. J. Syst. Evol. Microbiol. 63(3), 95964, Doi: 10.1099/ijs.0.043703-0.

[26] Kuever, J., Könneke, M., Galushko, A., Drzyzga, O. (2001) Reclassification of Desulfobacterium phenolicum as Desulfobacula phenolica comb. nov. and description of strain SaxT as Desulfotignum balticum gen. nov., sp. nov. Int. J. Syst. Evol. Microbiol. 51(1), 171-7, Doi: 10.1099/00207713-51-1-171.

[27] Kuykendall, L.D., Roy, M.A., O’Neill, J.J., Devine, T.E. (1988) Fatty Acids, Antibiotic Resistance, and Deoxyribonucleic Acid Homology Groups of Bradyrhizobium japonicum. Int. J. Syst. Evol. Microbiol. 38(4), 358-61, Doi: 10.1099/00207713-38-4-358.

[28] Lefèvre, C.T., Bazylinski, D.A. (2013) Ecology, diversity, and evolution of magnetotactic bacteria. Microbiol Mol Biol Rev 77(3), 497-526.

[29] Lefèvre, C.T., Howse, P.A., Schmidt, M.L., Sabaty, M., Menguy, N., Luther, G.W., Bazylinski, D.A. (2016) Growth of magnetotactic sulfate-reducing bacteria in oxygen concentration gradient medium. Environ. Microbiol. Rep., Doi: $10.1111 / 1758-2229.12479$.

[30] Lefèvre, C.T., Menguy, N., Abreu, F., Lins, U., Pósfai, M., Prozorov, T., Pignol, D., Frankel, R.B., Bazylinski, D.A. (2011) A cultured greigite-producing magnetotactic bacterium in a novel group of sulfate-reducing bacteria. Science 334(6063), 1720-3, Doi: $10.1126 /$ science. 1212596.

[31] Lefèvre, C.T., Trubitsyn, D., Abreu, F., Kolinko, S., de Almeida, L.G.P., de Vasconcelos, A.T.R., Lins, U., Schüler, D., Ginet, N., Pignol, D., Bazylinski, D.A. (2013) Monophyletic origin of magnetotaxis and the first magnetosomes. Environ. Microbiol. 15(8), 2267-74, Doi: 10.1111/1462-2920.12097.

[32] Lefèvre, C.T., Trubitsyn, D., Abreu, F., Kolinko, S., Jogler, C., de Almeida, L.G.P., de Vasconcelos, A.T.R., Kube, M., Reinhardt, R., Lins, U., Pignol, D., Schüler, D., Bazylinski, D.A., Ginet, N. (2013) Comparative genomic analysis of magnetotactic bacteria from the Deltaproteobacteria provides new insights into magnetite and greigite magnetosome genes required for magnetotaxis. Environ. Microbiol. 15, 2712-35, Doi: 10.1111/1462-2920.12128.

[33] Lemos, R.S., Gomes, C.M., Santana, M., LeGall, J., Xavier, A.V., Teixeira, M. (2001) The "strict" anaerobe Desulfovibrio gigas contains a membrane-bound oxygen-reducing respiratory chain. FEBS Lett. 496(1), 40-3.

[34] Lin, W., Pan, Y. (2015) A putative greigite-type magnetosome gene cluster from the candidate phylum Latescibacteria. Environ. Microbiol. Rep. 7(2), 237-42, Doi: $10.1111 / 1758-2229.12234$. 
[35] Mann, S., Sparks, N.H.C., Frankel, R.B., Bazylinski, D.A., Jannasch, H.W. (1990) Biomineralization of ferrimagnetic greigite (Fe3S4) and iron pyrite (FeS2) in a magnetotactic bacterium. Nature 343(6255), 258-61, Doi: 10.1038/343258a0.

[36] Maratea, D., Blakemore, R.P. (1981) Aquaspirillum magnetotacticum sp nov, a magnetic spirillum. Int. J. Syst. Bacteriol. 31(4), 452-5.

[37] Matsunaga, T., Sakaguchi, T., Tadakoro, F. (1991) Magnetite formation by a magnetic bacterium capable of growing aerobically. Appl. Microbiol. Biotechnol. 35(5), 651-5, Doi: 10.1007/BF00169632.

[38] Miller, L.T. (1982) Single derivatization method for routine analysis of bacterial whole-cell fatty acid methyl esters, including hydroxy acids. J. Clin. Microbiol. 16(3), 584-6.

[39] Rodriguez-R, L.M., Konstantinidis, K.T. (2014) Bypassing cultivation to identify bacterial species: culture-independent genomic approaches identify credibly distinct clusters, avoid cultivation bias, and provide true insights into microbial species. Microbe Mag. 9(3), 111-8, Doi: 10.1128/microbe.9.111.1.

[40] Sakaguchi, T., Arakaki, A., Matsunaga, T. (2002) Desulfovibrio magneticus sp nov., a novel sulfate-reducing bacterium that produces intracellular single-domain-sized magnetite particles. Int. J. Syst. Evol. Microbiol. 52, 215-21.

[41] Schleifer, K.H., Schüler, D., Spring, S., Weizenegger, M., Amann, R., Ludwig, W., Kohler, M. (1991) The genus Magnetospirillum gen. nov. description of Magnetospirillum gryphiswaldense sp. nov. and transfer of Aquaspirillum magnetotacticum to Magnetospirillum magnetotacticum comb. nov. Syst. Appl. Microbiol. 14(4), 379-85.

[42] Schübbe, S., Kube, M., Scheffel, A., Wawer, C., Heyen, U., Meyerdierks, A., Madkour, M.H., Mayer, F., Reinhardt, R., Schüler, D. (2003) Characterization of a spontaneous nonmagnetic mutant of Magnetospirillum gryphiswaldense reveals a large deletion comprising a putative magnetosome island. J. Bacteriol. 185(19), 5779-90.

[43] Simmons, S.L., Bazylinski, D.A., Edwards, K.J. (2007) Population dynamics of marine magnetotactic bacteria in a meromictic salt pond described with qPCR. Environ. Microbiol. 9(9), 2162-74, Doi: 10.1111/j.1462-2920.2007.01330.x.

[44] Simmons, S.L., Edwards, K.J. (2007) Unexpected diversity in populations of the many-celled magnetotactic prokaryote. Environ. Microbiol. 9(1), 206-15, Doi: 10.1111/j.1462-2920.2006.01129.x.

[45] Simmons, S.L., Sievert, S.M., Frankel, R.B., Bazylinski, D.A., Edwards, K.J. (2004) Spatiotemporal distribution of marine magnetotactic bacteria in a seasonally stratified coastal salt pond. Appl. Environ. Microbiol. 70(10), 6230-9, Doi: 10.1128/AEM.70.10.6230-6239.2004.

[46] Spring, S., Bazylinski, D.A. (2006) Magnetotactic Bacteria. In: Dr, M.D.P., Falkow, S., Rosenberg, E., Schleifer, K.-H., Stackebrandt, E., (Eds.), The Prokaryotes, Springer New York, pp. 842-62.

[47] Stamatakis, A. (2014) RAxML version 8: a tool for phylogenetic analysis and postanalysis of large phylogenies. Bioinforma. Oxf. Engl. 30(9), 1312-3, Doi: 10.1093/bioinformatics/btu033.

[48] Strittmatter, A.W., Liesegang, H., Rabus, R., Decker, I., Amann, J., Andres, S., Henne, A., Fricke, W.F., Martinez-Arias, R., Bartels, D., Goesmann, A., Krause, L., 
Pühler, A., Klenk, H.-P., Richter, M., Schüler, M., Glöckner, F.O., Meyerdierks, A., Gottschalk, G., Amann, R. (2009) Genome sequence of Desulfobacterium autotrophicum HRM2, a marine sulfate reducer oxidizing organic carbon completely to carbon dioxide. Environ. Microbiol. 11(5), 1038-55, Doi: 10.1111/j.1462-2920.2008.01825.x.

[49] Tindall, B.J. (1990) A Comparative Study of the Lipid Composition of Halobacterium saccharovorum from Various Sources. Syst. Appl. Microbiol. 13(2), 128-30, Doi: 10.1016/S0723-2020(11)80158-X.

[50] Tindall, B.J. (1990) Lipid composition of Halobacterium lacusprofundi. FEMS Microbiol. Lett. 66(1), 199-202, Doi: 10.1016/0378-1097(90)90282-U.

[51] Vallenet, D., Belda, E., Calteau, A., Cruveiller, S., Engelen, S., Lajus, A., Le Fèvre, F., Longin, C., Mornico, D., Roche, D., Rouy, Z., Salvignol, G., Scarpelli, C., Thil Smith, A.A., Weiman, M., Médigue, C. (2013) MicroScope--an integrated microbial resource for the curation and comparative analysis of genomic and metabolic data. Nucleic Acids Res. 41(Database issue), D636-647, Doi: 10.1093/nar/gks1194.

[52] Wang, Y., Lin, W., Li, J., Pan, Y. (2013) High diversity of magnetotactic deltaproteobacteria in a freshwater niche. Appl. Environ. Microbiol. 79(8), 2813-7, Doi: 10.1128/AEM.03635-12.

[53] Wenter, R., Wanner, G., Schüler, D., Overmann, J. (2009) Ultrastructure, tactic behaviour and potential for sulfate reduction of a novel multicellular magnetotactic prokaryote from North Sea sediments. Environ. Microbiol. 11(6), 1493-505, Doi: 10.1111/j.1462-2920.2009.01877.x.

[54] Widdel, F., Pfennig, N. (1981) Studies on dissimilatory sulfate-reducing bacteria that decompose fatty acids. I. Isolation of new sulfate-reducing bacteria enriched with acetate from saline environments. Description of Desulfobacter postgatei gen. nov., sp. nov. Arch. Microbiol. 129(5), 395-400.

[55] Williams, T.J., Lefèvre, C.T., Zhao, W., Beveridge, T.J., Bazylinski, D.A. (2012) Magnetospira thiophila gen. nov., sp. nov., a marine magnetotactic bacterium that represents a novel lineage within the Rhodospirillaceae (Alphaproteobacteria). Int. J. Syst. Evol. Microbiol. 62(Pt 10), 2443-50, Doi: 10.1099/ijs.0.037697-0.

[56] Wolfe, R.S., Thauer, R.K., Pfennig, N. (1987) A “capillary racetrack" method for isolation of magnetotactic bacteria. FEMS Microbiol. Lett. 45(1), 31-5, Doi: 10.1016/0378-1097(87)90039-5.

[57] Zhang, R., Chen, Y.-R., Du, H.-J., Zhang, W.-Y., Pan, H.-M., Xiao, T., Wu, L.-F. (2014) Characterization and phylogenetic identification of a species of spherical multicellular magnetotactic prokaryotes that produces both magnetite and greigite crystals. Res. Microbiol. 165(7), 481-9, Doi: 10.1016/j.resmic.2014.07.012.

[58] Zhou, K., Zhang, W.-Y., Yu-Zhang, K., Pan, H.-M., Zhang, S.-D., Zhang, W.-J., Yue, H.-D., Li, Y., Xiao, T., Wu, L.-F. (2012) A novel genus of multicellular magnetotactic prokaryotes from the Yellow Sea. Environ. Microbiol. 14(2), 405-13, Doi: $10.1111 / \mathrm{j} .1462-2920.2011 .02590 . x$. 